УДК 378.018.8:364-051

\author{
Оксана Шевчук, \\ кандидат педагогічних наук, доцент, \\ дочент кафедри соичіальної \\ педагогіки та сочіальної роботи \\ Уманського державного \\ педагогічного університету \\ імені Павла Тичини
}

\title{
ОСНОВИ ЦІЛІСНОГО ГАРМОНІЙНОГО РОЗВИТКУ ОСОБИСТОСТІ МАЙБУТНІХ СОЦІАЛЬНИХ ПРАЦІВНИКІВ У ПРОЦЕСІ ПРОФЕСІЙНОЇ ПІДГОТОВКИ
}

У статті на основі теоретичного обгрунтування наукової проблеми, вивчення сучасної практики визначено основи цілісного гармонійного розвитку особистості майбутніх соціальних працівників у процесі професійної підготовки. Схарактеризовано поняттєво-категоріальний апарат та розкрито суть та структуру изілісного гармонійного розвитку особистості майбутніх соціальних працівників. Встановлено, щзо процес професійної підготовки майбутніх сочіальних працівників забезпечує цілісний вплив на особистість майбутнього фахівцяя, його емоційноціннісну, когнітивно-світоглядну й діяльнісно-вольову сфери, стимулює прочеси самовиховання, саморозвитку й самоорганізації особистості.

Ключові слова: сочіальна сфера, сочіальний прачівник, сочіальна робота, практична підготовка, професійна підготовка, иілісний розвиток, гармонійний розвиток, особистість.

The article reveales the scientific problem, which includes the following: the study of modern practice, the basis of the holistic, harmonious development of the personality of future social workers in the process of vocational training which are based on the theoretical substantiation. It characterizes the conceptual-categorical apparatus and the essence and structure of the integral, harmonious development of future social workers' personality. The author mentions that the process of professional training of future social workers has provided a holistic influence on the personality of the future specialist, his emotional-value, cognitive-ideological and activity-volitional sphere and stimulates the processes of self-education, self-development and selforganization of the individual. The idea of a holistic, harmonious development of future social workers' personality is mentioned in the content of the professional training of the future specialists (the content of the educational and professional training program, curriculum, professional practice and individual 
work) throughout the entire period of training, which ensures the continuity of the process of professional training in higher education institutions. On the basis of representations of the ideal, holistic, harmonious personality, described in psychological and pedagogical science, the concepts of «integrity of the person», "harmony of the person» have been studied. It represents the unity of ideological orientation, manifested in the autonomy of the individual, his responsibility for his actions, reflexivity, ability to self-esteem, as well as in the ability to self-development and self-realization. It is substantiated that integrity and harmony are necessary characteristics of the personality of future social workers in the transformational conditions of modern society.

Keywords: social sphere, social worker, social work, practical training, professional training, holistic development, harmonious development, personality.

В умовах гуманізації суспільства цілісний розвиток особистості, іiі потенційних можливостей $\epsilon$ актуальною проблемою. Сучасне суспільство потребує активних, творчих особистостей, здатних реалізовувати свій потенціал, власні здібності, будувати гармонійні відносини не тільки 3 оточуючими, а й із самим собою. Крім цього, постійно прагнути до самовдосконалення, бути активним суб'єктом свого життя.

Сучасну ситуацію соціального розвитку можна охарактеризувати як період постійних змін. Зміни відбуваються як на загальносвітовому рівні, так і на рівні держави. Зміни на рівні суспільства виробляють зміни в соціальних інститутах, таких як університет, школа, сім'я. Це в свою чергу створює необхідність для змін в світогляді кожної окремої особистості. Така соціальна ситуація розвитку створює необхідність для розробки нових психолого-педагогічних технологій, метою яких було б цілісне формування, відповідних соціальній ситуації розвитку, психічних новоутворень особистості.

Соціально-економічні зміни в нашій державі зумовлюють i стратегічні зміни в системі освіти сьогодення: пріоритетом розвитку освіти України $є$ курс на перетворення іiі на якісну галузь, збагачену дієвими теоретичними і практичними розробками, забезпечену високоякісними кадрами, враховуючи той факт, що успіх формування духовності особистості знаходиться у прямій залежності від рівня професійної підготовки фахівців, систематичного вдосконалення та підвищення їх кваліфікації.

Соціальне замовлення на компетентних фахівців, які ефективно функціонуватимуть у професійній діяльності, визначене Законом України «Про вищу освіту» (2014р.), проектом Закону України «Про виховання дітей та молоді» (2005р.), Законом України «Про сприяння соціальному становленню та розвитку молоді в Україні» (1993 р., зі змінами), 
Національною рамкою кваліфікацій, Державним освітнім стандартом вищої освіти й Національною стратегією розвитку освіти в Україні на 2012-2021 pp., спрямовує заклади вищої освіти на підвищення якості фахової підготовки та розв'язання цілої низки завдань. Засади та принципи державної політики у сфері освіти орієнтують нас на єдність навчання, виховання та розвитку особистості. Цілісність розвитку - це нерозривна єдність навчання та виховання, а також розвитку i формування особистості. Розвиток особистості - це процес становлення особистості під дією зовнішнього впливу виховання, навчання, соціального середовища.

Важливе значення проблема цілісного розвитку особистості займає в процесі професійної підготовки в умовах навчання у закладах вищої освіти. Майбутня успішність професійної діяльності студента неабиякою мірою залежить від того, наскільки індивідуально-психологічні особливості фахівця відповідають вимогам професії, наскільки повно особистість сприймає вимоги, цінності, традиції, норми і правила поведінки, відпрацьовані у навчальному середовищі [2, с. 69].

Тому, на нинішньому етапі розвитку вищої освіти важливою особливістю підготовки майбутніх соціальних працівників до професійної діяльності у закладах вищої освіти $€$ розв'язання провідних завдань: формування особистості шляхом патріотичного, правового, екологічного виховання; утвердження в учасників освітнього процесу моральних цінностей, соціальної активності, громадянської позиції та відповідальності, здорового способу життя, вміння вільно мислити та самоорганізовуватися в сучасних умовах [5]. Сучасному суспільству потрібні кваліфіковані спеціалісти 3 виробленою здатністю ефективно створювати базу для формування особистісної культури спеціаліста, формування системи ціннісних ставлень до світу, до самого себе; для реалізації всіх найкращих потенцій, закладених у людині, формувати особистість до співробітництва, спрямованого на засвоєння вироблених людством культурних цінностей; забезпечення всебічного розвитку,

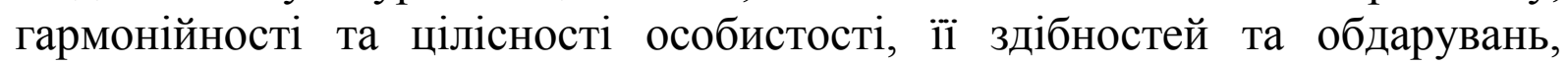
збагачення на цій основі інтелектуального потенціалу народу, його духовності й культури, формування громадянина України, здатного до самостійного мислення, соціального вибору і подальшої діяльності [4].

Для того щоб відчувати себе впевнено в ситуації постійних змін, щоб адекватно на них реагувати, майбутній соціальний працівник повинен активізувати свій творчий потенціал, а також зуміти допомогти собі розкрити власні здібності, спрямувати їх на розв'язання проблеми, що виникла. Усе це визначає завдання формування майбутнього соціального працівника - цілісний гармонійний розвиток майбутнього фахівця, креативного, компетентного, готового до творчого здійснення професійної діяльності. 
Тому, перед закладами вищої освіти постає важливе завдання, орієнтоване на створення такого освітнього середовища, яке б сприяло формуванню освіченої, цілісної, гармонійно розвиненої особистості, здатної до постійного оновлення знань, швидкої адаптації до змін в соціально-культурній сфері. У зв'язку з цим, необхідно організовувати відповідного роду діяльність, яка б допомагала студенту в його особистісному, цілісному гармонійному розвитку.

Проблема розвитку особистості у процесі професійної підготовки у вітчизняній та зарубіжній науці не $\epsilon$ новою. Так, в українській освітянській літературі останніх років до проблеми формування особистості зверталися такі вчені, як В. Андрущенко, С. Гончаренко, М. Свтух, І. Зязюн, В. Кремень, В. Кушерець, О. Савченко, О. Сердюк, І. Надольний, В. Огнев'юк та ін.

Значний внесок у визначення напрямів створення особистісноорієнтованого навчання i виховання спрямованого на всебічний гармонійний розвиток особистості - у дослідженнях відомих психологів $\mathrm{i}$ педагогів Г. Балла, Г. Костюка, І. Кона, В. Сухомлинського, К. Платонова, В. Чудновського, І. Якиманської у педагогічних надбаннях Ш. Амонашвілі, I. Волкова, І. Іванова, А. Макаренка, С. Лисенкової, К. Ушинського та ін.

Розробкою теоретико-методологічних засад соціальної роботи займаються вітчизняні вчені: В. Буяшенко, О. Карагодіна, Н. Коляда, В. Лютий, В. Полтавець, Т. Семигіна, Т. Сила, Л. Тюптя, С. Шандрук, Т. Шаповалова, А. Ярошенко та ін.

Питання підготовки майбутнього спеціаліста до соціальнопедагогічної діяльності, розвитку професіоналізму та компетентності майбутніх соціальних педагогів та соціальних працівників в Україні проаналізовано в працях С. Архипової, Р. Вайноли, Ю. Галагузової, Л. Гуслякової, А. Капської, О. Карпенко, Б. Келасьєва, І. Козубовської, Г. Лактіонова, Л. Міщик, Л. Петришин, В. Поліщук, В. Сластьоніна, В. Радула С. Тетерського, В. Фокіна, С. Чистякової, Н. Шмельової та ін. Підготовку майбутніх соціальних педагогів до гармонізації гендерних взаємин у молодіжному середовищі досліджувала Н. Байдюк.

Проблему гармонії та гармонізації в різних сферах діяльності (управління, економіка, фізичне виховання, соціологія) досліджують О. Бондар, Т. Бондаренко, Т. Бєрсєнєва, В. Єлагін, О. Калашніков, В. Клочко, Л. Пашко, Н. Попова, В. Рудько, Ю. Тищенко, Н. Шевандрин та ін.

Становлення та розвиток цілісної особистості досліджують Н. Авер'янова, Т. Воропаєва, О. Гаджаман, С. Гейко, В. Федяєва та ін.

Мета статті - на основі теоретичного обгрунтування наукової проблеми, вивчення сучасної практики визначити основи цілісного гармонійного розвитку особистості майбутніх соціальних працівників у процесі професійної підготовки. 
Система вищої освіти забезпечує необхідний рівень професіоналізму майбутнього фахівця, можливості його самореалізації в процесі навчання, виховання, практики та в позанавчальній діяльності. Для успішної реалізації творчого та особистісного потенціалу майбутнього спеціаліста необхідно формувати професійну спрямованість студентів, створювати сприятливий клімат у навчальному закладі, студентському колективі та умови, що сприяють самореалізації особистості, розкритті іiі індивідуальних здібностей, формуванню ціннісних орієнтацій.

У дослідженнях Д. Пивоварова [8] зазначається, що визначення типу будь-якої цілісності можливо на основі характеру зв'язку та ступеня злитості іiі частин. Існує три варіанти зв'язку цілого і його частин, які помітно відрізняються один від одного. Їх взаємний вплив свідчить про доцільність виділення трьох основних типів цілісності: тоталітарної, партитивної і гармонійної.

Гармонійна цілісність людини являє собою справжню єдність, завершену узгодженість всіх природних, соціальних і духовних складових iï сутності. Носій гармонійної цілісності цілком послідовно веде здоровий спосіб життя, проявляє душевну схильність і любов до людей, творчо здійснює освоєння доступної дійсності.

Отже, цілісна особистість - це особистість, компоненти якої узгоджені. Духовне, природне і соціальне знаходиться в єдності. Цілісний розвиток особистості передбачає іiі гармонійний розвиток.

Цілісність особистості - це таке з'єднання іiі частин, яке створює міцну i гармонійну цілісність. Можна говорити про зовнішню, або загальну цілісність особистості, маючи на увазі гармонійну єдність іiі фізичного, душевного і духовно-морального життя. Цілісність особистості передбачає відповідність змісту внутрішнього життя людини і його зовнішньої діяльності.

Цілісність особистості - це здатність людини в критичних ситуаціях зберігати свою життєву стратегію, залишатися прихильним своїх життєвих позицій i ціннісних орієнтацій. Це особистість, яка $\epsilon$ одночасно автономною - і відкритою до людей і життя.

Особистість $є$ цілісною тоді, коли людина має сміливість подивитися на речі реалістично, робити власні висновки i, якщо необхідно, сказати про це, в тому числі протистоячи зовнішньому тиску. Це особистість, у якої $є$ стійка думка і система цінностей. Це людина, яку не терзають протиріччя, у якої всередині спокій і впевненість.

Зазвичай цілісний розвиток має на увазі всебічність, гармонійність. Тобто розвиток всіх основних - фізичних, моральних, інтелектуальних, естетичних - здібностей особистості.

Проблема гармонії та гармонізації особистості нерозривно пов'язана з проблемою динаміки розвитку особистості, iї якісних новоутворень. 
Гармонія, гармонійність - внутрішня і зовнішня упорядкованість, узгодженість, цілісність явищ і процесів. У психології - поєднання індивідуальних чи особистісних позитивних рис. Гармонія виробляється у процесі виховання особи й участі ії в життєдіяльності певного колективу $[1$, c. 63].

Гармонізація особистості - це процес особистісного розвитку, спрямований на досягнення психологічної гармонії. До поняття «особистісна гармонія» наближаються поняття саморегуляції, саморозвитку та самоактуалізації.

Гармонізація - це завжди прагнення до збільшення цілісності, повноти свого становлення та самовиявів, прагнення до їх різнобічності й загальності, що, звичайно, може поєднуватися з утворенням певної часової ієрархії переваг у відносинах і справах.

В «Українському педагогічному словнику» (1997р.) гармонійний розвиток тлумачиться як співрозмірний розвиток фізичних і рухових сил людини, струнке й строге поєднання різних сторін і функцій іiі свідомості, поведінки й діяльності [1, с. 63].

Особистість - феномен одночасно індивідуального, соціального i духовного буття. Внутрішня гармонія неможлива без гармонійних зв'язків з соціальним оточенням. У свою чергу, гармонія міжособистісних відносин передбачає гармонію індивіда з самим собою.

Особистість - відображення соціальної природи людини, розгляду iї як індивідуальності та суб'єкта соціокультурного життя, що розкривається в контекстах соціальних відносин, спілкування і предметної діяльності, соціально зумовлена система психічних якостей індивіда, що визначається залученістю людини до конкретних суспільних, культурних, історичних відносин.

Під особистістю розуміють стійку систему соціально значущих рис, що характеризують особу як члена того чи іншого суспільства або спільноти. Поняття «особистість» характеризує суспільну сутність людини, пов'язану із засвоєнням різноманітного виробничого і духовного досвіду суспільства.

Отже, особистістю можна назвати людину, яка досягла такого рівня соціального розвитку і самосвідомості, який дозволяє їй знаходити $\mathrm{i}$ обирати серед цінностей культури особистісні смисли, самостійно виконувати відповідну перетворювальну діяльність, свідомо і відповідально здійснювати саморегуляцію діяльності й поведінки.

Розвиток особистості - процес соціального розвитку людини, становлення іï як суб'єкта діяльності, члена суспільства, громадянина. Виявляється і формується вона в процесі свідомої діяльності й спілкування. Поєднує в собі риси загальнолюдського, суспільно значущого, індивідуального та неповторного. 
Студентство визначають як своєрідну мобільну групу, метою діяльності якої $\epsilon$ засвоєння за спеціально організованою програмою соціально-професійних ролей, підготовка до виконання важливих соціальних функцій: професійних, культурологічних, громадськополітичних, сімейних тощо. Студент вищого закладу освіти - це молода людина, яка характеризується професійною спрямованістю, готується до висококваліфікованого виконання функцій фахівця в певній професійній галузі. Головними напрямами життєдіяльності студентів $є$ професійне навчання, особистісне зростання й самоствердження, розвиток інтелектуального потенціалу, духовне збагачення, моральне, естетичне, фізичне самовдосконалення - і все це характеризує цілісну особистість.

Але без достатньо позитивної мотивації неможливо досягти результатів у цілісному гармонійному розвитку особистості під час навчання у вищих закладах освіти. Позитивними мотивами пізнавальної діяльності можуть виступати: почуття обов'язку, усвідомлення значущості оволодіння професією, інтерес до навчання і окремих наук, відчуття задоволення від пізнання нового матеріалу, вирішення складних завдань. На мотивацію також впливає зміст занять, методика викладання, особистість викладача, стосунки в студентському колективі, змагання, досягнуті результати.

Тому, щоб розвиток особистості студента у вищих закладах освіти набув цілісності та гармонійності, необхідною умовою є: на старших курсах приділяти особливу увагу діалоговим формам спілкування зі студентами, зокрема, в процесі виконання ними курсових та кваліфікаційних робіт, проходження практик тощо; розвивати самостійні, активні і творчі форми навчальної роботи. Це і творча участь у семінарах та практичних заняттях, безпосередня участь в роботі лабораторій, участь в конкурсах студентських робіт тощо.

Ми розглядаємо гармонію особистості як психологічну норму живої системи, що має підсистеми: «людина - середовище» як зовнішній простір i «людина - людина» як внутрішній простір особистості.

Виділяють дві групи загальних критеріїв - ознак психологічної гармонійності особистості, іiї стану і життєдіяльності:

1) екологічні відносини 3 собою i навколишнім світом. Виражаються як позитивна Я-концепція, конструктивні, співробітницькі стосунки з людьми, почуття єдності з живою і неживою природою, хороша адаптація в різних природних середовищах;

2) корисне, стійке, тривале, творче та економічне функціонування й розвиток індивіда, інших людей та навколишньої природи в різноманітних життєвих середовищах [7, с. 3400].

Гармонія - це врівноваженість і єдність в гармонійному цілому зовнішньому й внутрішньому просторі особистості. Модель внутрішнього 
простору особистості включає в себе три взаємопов'язані сфери: когнітивну, емоційну та поведінково-діяльнісну.

Гармонізація - це процес встановлення гармонії між складовими елементами будь-якої системи, процесу, явища. Гармонізація стосовно людини як соціального суб'єкта передбачає узгоджене, врівноважене

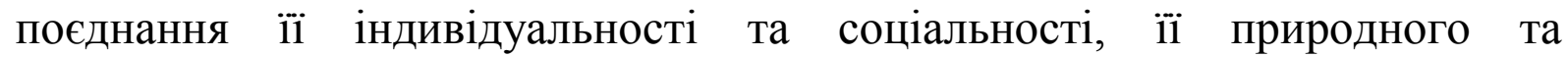
культурного начала, що забезпечує якісну самореалізацію людини та розвиток іiі соціального середовища [3, с. 385].

Гармонійний розвиток особистості - процес домірних, злагоджених якісних і кількісних позитивних змін людини, як біологічної, психічної та соціальної істоти, протягом життя; відповідність та узгодженість розвитку разом взятих розуму та свідомості, волі та почуттів, поведінки та діяльності, фізичних i духовних сил суспільної особи протягом іiі існування; пропорційне збагачення та відповідне вдосконалення цінностей, рис характеру, поведінки та діяльності людини в онтогенезі.

Гармонійний розвиток особистості - це різнобічний процес набуття та вдосконалення іiі фізичних, психологічних, моральних i економічних якостей в їх розмірності й органічній єдності. Гармонійний розвиток особистості означає всебічний розвиток людини як створіння соціального, яке володіє свідомістю (розумом), активного та здатного до результативної і продуктивної праці [3, с. 131-133].

Гармонізації внутрішнього світу особистості сприяють: розуміння себе, адекватна самооцінка своїх особистісних та професійно значущих рис і якостей, дій і вчинків; усвідомлення самого себе у контексті взаємин 3 собою, іншими людьми, суспільством; відповідність, зближення Яреального та Я-ідеального, намагання бути таким, яким би хотів себе бачити; прийняття себе реального, справжнього, віра у свої можливості, значущість, привабливість, неповторність, унікальність; осмисленість життя і власної професійної діяльності, усвідомлення та прийняття меж своєї свободи у ставленні до інших людей, навколишнього світу, відповідальність перед своїм «Я» за вибір цінностей, стратегій життя i поведінки; сформованість гнучкої Я-концепції, що призводить автоматично до зміни поведінки у результаті перебудови уявлень про себе; здатність знаходити баланс професійного та індивідуального; прагнення до самозмін і саморозвитку, творчої самореалізації у професії. Розуміння шляхів гармонізації свого внутрішнього світу сприяє позитивному емоційному сприйняттю себе та інших, допомагає уникати стресових i конфліктних ситуацій [6, с. 330].

Цілісний гармонійний розвиток особистості передбачає дотримання єдності та взаємодії п'яти частин виховання. Традиційними складовими частинами виховання називають розумове, фізичне, трудове, моральне й естетичне. 
Цілісна всебічно розвинута гармонійна особистість завжди шукає ідеал в житті, прагне пізнати світ, природу у всій красі. Тому їй неприйнятні поняття «дисгармонія», «хаос», «безлад», «незлагодженість», що $є$ великими ворогами не тільки розвитку особистості, а й суспільства взагалі.

Цілісно розвинена особистість - варіант розвиненої особистості, особистість з рівномірним розвитком усіх сторін, яка живе без внутрішніх конфліктів, з внутрішньої гармонією.

Отже, цілісний розвиток людини відбувається тоді, коли $\epsilon$ можливість знайти себе, стати собою, жити в гармонії з природою і робити свою справу. Розвинути впевненість у собі можна тільки завдяки використанню власних можливостей - шляхом реалізації індивідуальності та формування гармонійної особистості. У просторі ціннісних вимірів «цілісність» постає у вигляді цілей виховання та виборі стратегій особистісного розвитку. Але найголовнішим $\epsilon$ те, що в системі чинників цілісного розвитку присутня активність самої особистості.

Формування особистості людини триває все життя, втім період навчання у вищий школі відіграє особливу роль у цьому процесі. Саме в цей час у студента закладаються основи тих якостей спеціаліста, з якими він ввійде в нову для нього атмосферу професійної діяльності, де відбуватиметься його подальший розвиток як особистості. Тому питання особистісного становлення студентів в аспекті їхньої професійної діяльності має постійно знаходитися в центрі уваги вищої школи.

Мета підготовки фахівця 3 соціальної роботи полягає в наданні допомоги людям у встановленні більш тісної, гармонійної взаємодії 3 навколишнім середовищем на різних рівнях, аж до рівня всього суспільства в цілому. Практична соціальна робота спрямована на встановлення взаємовідносин між людьми, організаціями або соціальними системами, якщо ці відносини конфліктні і заважають людині повноцінно жити i працювати. Отже, щоб мати змогу допомогти іншим людям, майбутній соціальний працівник має стати цілісно розвиненою, гармонійною особистістю. Для цього процес професійної підготовки майбутніх соціальних працівників повинний бути вибудуваний на грунті цілісного розвитку студента і як особистості, і як фахівця.

\section{СПИСОК ВИКОРИСТАНИХ ДЖЕРЕЛ}

1. Гончаренко С. У. Український педагогічний словник. Київ: Либідь, 1997. $376 \mathrm{c}$.

2. Гусак В. М. Шляхи формування професійної культури майбутніх соціальних працівників в умовах університету. Наукові праці [Чорноморського державного університету імені Петра Могили комплексу «Києво-Могилянська академія»]. Сер.: Педагогіка. 2010. 
Т. 136. Вип. 123. С. 69-73.

3. Енциклопедія для фахівців соціальної сфери / за заг. ред. проф. І. Д. Звєрєвої. 2-ге вид. Київ, Сімферополь: Універсум, 2013. 536 с.

4. Закон України «Про виховання дітей та молоді»: проект. Освіта України. 2004. № 72. С. 4-6.

5. Закон України «Про вищу освіту». 2014. URL: http://www.zakon. rada.gov.ua/laws/show/1556-18 (дата звернення: 1.07.2014).

6. Мелешко Г., Мелешко О. Психолого-педагогічний тренінг як засіб гармонізації особистості майбутнього вчителя. Украӥнський науковий журнал «Освіта регіону. Політологія. Психологія. Комунікаиії». 2013. № 3. C. 330-336.

7. Пазекова Г. Е., Пазеков Е. В. Феноменология психологической гармонии личности. Фундаментальные исследования. 2015. № 2-15. C. 3399-3403.

8. Пивоваров Д. В. Онтология религии. Санкт-Петербург: Владимир Даль, 2009. 506 с. 